\title{
Reactive Natural Phosphate in Safflower Fertilization in Cerrado Oxisol
}

\author{
Edna Maria Bonfim-Silva ${ }^{1}$, Luana Glaup Araújo Dourado ${ }^{2}$, Denise César Soares ${ }^{1}$, Túlio Martinez Santos ${ }^{2}$, \\ Tonny José Araújo da Silva ${ }^{1} \&$ William Fenner ${ }^{2}$ \\ ${ }^{1}$ Institute of Agricultural and Technological Sciences, Federal University of Mato Grosso, Rondonópolis, Brazil \\ ${ }^{2}$ Faculty of Agronomy and Zootechnic, Federal University of Mato Grosso, Cuiabá, Brazil \\ Correspondence: Edna Maria Bonfim-Silva, Institute of Agricultural and Technological Sciences, Federal \\ University of Mato Grosso, 5055 Students Avenue, Rondonópolis, Brazil. E-mail: embonfim@hotmail.com
}

Received: June 1, 2019

Accepted: July 14, $2019 \quad$ Online Published: September 15, 2019

doi:10.5539/jas.v11n15p135

URL: https://doi.org/10.5539/jas.v11n15p135

\begin{abstract}
Fertilizer management has a direct influence on crop productivity, especially phosphorus, which is most limiting to the development of crops in tropical soils due to the genesis of these soils. In this sense, it is necessary to use nutrient sources that are agronomically efficient at reduced costs compared to conventional sources. Thus, the objective of the present study was to evaluate the effects of reactive natural phosphate as a source of phosphorus on the development, growth, and yield of safflower in Cerrado Oxisol. The experiment was carried out in a greenhouse at the Federal University of Mato Grosso, Campus of Rondonópolis. The completely randomized design consisted of the following treatments: $0,100,200,400$ and $600 \mathrm{mg} \mathrm{dm}^{-3}$ of reactive natural phosphate (Bayóvar reactive phosphate), with 6 replicates, consisting by pots with $2 \mathrm{dm}^{3}$ of capacity. To the Oxisol used to fill the plots was incorporated dolomitic limestone to increase base saturation to60\%. Safflower cultivar used was IMA 0213 with a final population of three plants per plot. Plant height, number of leaves and chlorophyll index were evaluated at 15,30, 45 and 55 days after emergence. In the last evaluation plants were cut and the number and diameter of the chapters, shoot and chapters dry mass, volume and root dry mass were also evaluated. The results were submitted to analysis of variance and regression up to $10 \%$ probability. In general, safflower crop shows a positive response to application of reactive natural phosphate. Doses between 389 and $600 \mathrm{mg} \mathrm{dm}^{-3}$ promoted best results for development and safflower production in an Oxisol.
\end{abstract}

Keywords: Carthamus tinctorius L., Bayóvar, oilseed, fertilizer management, alternative crops

\section{Introduction}

The increased demand for biofuels has now been the main reason for the growth of research on alternative energy. Faced with the need for new energy sources, the large-scale use of biomass energy is seen as an option that could contribute to more sustainable development. Thus, the importance of oilseed crops, especially safflower (Carthamus tinctorius L.), has increased, especially with interest in the production of biofuels (Dordas \& Sioulas, 2008).

According to Coronado (2010), safflower is an oleaginous crop cultivated for more than two millennia, and its raw material is destined for the production of oil both for human consumption and for the industry with diverse uses (Shahrokhnia \& Sepaskhah, 2016). Seeds have high oil content (27 to 47\%), presenting potential as raw material for biodiesel production, as well as minerals ( $\mathrm{Zn}, \mathrm{Cu}, \mathrm{Mn}$ and $\mathrm{Fe}$ ), vitamins (thiamine and $\beta$-carotene) and tocopherols ( $\alpha, \beta$ and $\gamma$ ), of a high quality oil (Velasco et al., 2005).

Safflower cultivation presents great productive and adaptable potential, as well as agronomic desirable characteristics, such as high quality and quantity of oil produced, tolerance to water deficit, soil salinity, high temperatures and low relative humidity air (Kizil, 2008), these characteristics justify their cultivation in regions with a hot climate and irregular rainfall, such as the Brazilian Cerrado in the dry period, diversifying the production in these areas, is therefore an alternative for crop rotation in Brazil (Anicésio et al., 2015; Bonfim-Silva et al., 2015).

Phosphorus $(\mathrm{P})$ is the most limiting nutrient for agricultural production in tropical soils, characterized by the high degree of weathering and low levels of available phosphorus in the plants (Novais \& Smyth, 1999; Bonser et al., 
1996; Rocha et al., 2005), as well as low phosphorus availability in the Oxisols, these present high phosphorus fixation capacity due to high acidity, low base saturation and cation exchange capacity, with predominance of iron and aluminum oxides in their mineralogy and high exchangeable aluminum content (Guedes et al., 2009; EMBRAPA, 2006).

In order to supply the required amount of phosphorus in agricultural crops in Cerrado soils where there is a predominance of Oxisols, the use of soluble phosphorus sources, such as superphosphates, promotes the immediate availability of the nutrient to the soil due to its greater agronomic efficiency, but their sources presents higher costs due to their process of industrialization, the deficit of reserves of quality phosphate rocks, and that part of the nutrient will be subject to fixation in the soil, reducing its availability to the plants (Lima et al., 2007; Horowitz \& Meurer, 2004).

An alternative to reducing costs with soluble phosphate fertilizers has been the use of less soluble phosphorus sources, such as reactive natural phosphates (Raij, 2011). The reactive natural phosphates have a lower acquisition cost and can reduce the fixation of phosphorus in the soil, since they react in a gradual way, presenting a residual effect that, when estimated for long periods, can have its effect equal to the soluble phosphates (Freire et al., 2005).

In this context, the objective was to evaluate doses of reactive natural phosphate as a source of phosphorus in the development, growth, and yield of safflower cultivation in Cerrado Oxisol.

\section{Material and Methods}

\subsection{Overview and Experimental Design}

The experiment was carried out in a greenhouse at the Federal University of Mato Grosso, Campus of Rondonópolis-MT, located geographically at latitude $16^{\circ} 27^{\prime} 49^{\prime \prime} \mathrm{S}$, longitude $54^{\circ} 34^{\prime} 47^{\prime \prime} \mathrm{W}$ and altitude of $284 \mathrm{~m}$. The region climate is classified as Aw according to Köppen, characterized by a warm and humid climate, with two defined seasons: one rainy in the summer, and another dry coinciding with the winter. The average temperature and relative humidity of the air during experiment were $27^{\circ} \mathrm{C}$ and $81 \%$, respectively.

\subsection{Soil Characterization and Preparation}

Soil used in the experiment was collected in an area under Cerrado vegetation in the 0-0.20 m depth layer of an Oxisol with a sandy-loam texture (EMBRAPA, 2013), sieving of $4 \mathrm{~mm}$ of opening to fill the experimental plots. A soil sample was sieved in a $2 \mathrm{~mm}$ aperture mesh for the chemical and granulometric characterization according to Embrapa (2011).

The analysis of Oxisol presented the following chemical and granulometric characteristics: $\mathrm{pH}\left(\mathrm{CaCl}_{2}\right)=4.0 ; \mathrm{P}$ $=1.1 \mathrm{mg} \mathrm{dm}^{-3} ; \mathrm{K}=43 \mathrm{mg} \mathrm{dm}{ }^{-3} ; \mathrm{Ca}=0.5 \mathrm{cmolc} \mathrm{dm}^{-3} ; \mathrm{Mg}=0.3 \mathrm{cmolc} \mathrm{dm}^{-3} ; \mathrm{Al}=1.2 \mathrm{cmolc} \mathrm{dm}^{-3} ; \mathrm{H}+\mathrm{Al}=7.4$ cmolc dm ${ }^{-3}$; O.M. $=28.9 \mathrm{~g} \mathrm{~kg}^{-1}$; sand $=425 \mathrm{~g} \mathrm{~kg}^{-1} ;$ silte $=100 \mathrm{~g} \mathrm{~kg}^{-1}$; e clay $=475 \mathrm{~g} \mathrm{~kg}^{-1}$; bases sum of $0.9 \mathrm{cmolc}$ $\mathrm{dm}^{-3} ; \mathrm{CEC}=8.3 \mathrm{cmolc} \mathrm{dm}^{-3} ; \mathrm{V}=11 \%$.

The soil acidity was corrected with the incorporation of dolomitic limestone (Relative Power of the Total Neutralization $($ PRNT) $=80.3 \%$ ), with the objective of increasing base saturation at the level of $60 \%$ (Anicésio et al., 2015). After liming, the soil was moistened and maintained at $60 \%$ of the maximum water retention capacity, remaining incubated for a period of 30 days.

The statistical design was completely randomized with five treatments and six replications, totaling 30 experimental plots, represented by plastic pots with a capacity of $2 \mathrm{dm}^{3}$ of soil. The treatments were constituted by the application of $0,100,200,400$ and $600 \mathrm{mg} \mathrm{dm}^{-3}$ of reactive natural phosphate ( $29 \%$ of total P) to the soil. It was used as a plant species, safflower (Carthamus tinctorius L.), cultivar IMA 0213, obtained from the germplasm bank of the Mato Grosso Cotton Institute (IMA), Brazil.

After the incubation period of the limestone, the soil was removed from the plastic bags and packed in the pots composing the experimental units. Ten seeds were sown per pot at a depth of $0.02 \mathrm{~m}$ and thinned at 7 and 15 days after plant emergence based on vigor, homogeneity and size criteria, establishing a final population of three plants per pot.

Planting fertilization was carried out simultaneously with the sowing of safflower. All treatments were also fertilized with nitrogen $(\mathrm{N})$, potassium $\left(\mathrm{K}_{2} \mathrm{O}\right)$ and micronutrients, with sources as urea, potassium chloride and FTE-BR 12, respectively.

Nitrogen fertilization was carried out in three equal rates, at 15, 30 and 45 days after emergence, with both applications performed as a solution. The potassium recommendation was $200 \mathrm{mg} \mathrm{dm}{ }^{-3}$ of $\mathrm{K}_{2} \mathrm{O}$ applied in the solid and granular form. Planting fertilization consisted of applying also $15 \mathrm{mg} \mathrm{dm}^{-3}$ of the formulated FTE-BR 
12 (Sulfur: $3.9 \%$, Copper: 0.85\%, Boron: 1.8\%, Manganese: $2.0 \%$ and Zinc: $9.0 \%$ ).

The reactive natural phosphate used comes from Bayóvar (Peru) and has 29\% phosphorus $\left(\mathrm{P}_{2} \mathrm{O}_{5}\right), 14 \%$ citric acid and $32 \%$ calcium in its composition (Farias, 2012), and the doses $\left(0,100,200,400\right.$ and $\left.600 \mathrm{mg} \mathrm{dm}^{-3}\right)$ were added to the soil at the time of planting.

Irrigation management was the gravimetric method. The maximum water retention capacity of the soil was determined in the laboratory, the pot capacity (maximum soil water retention capacity) was determined according to the methodology described by Bonfim-Silva et al. (2011). During the conduction of the experiment, the humidity was maintained at $60 \%$ of the maximum water retention capacity of the soil.

\subsection{Response Variables}

Plant growth and development evaluations were performed at 15, 30, 45 and 55 days after emergence (DAE), in which: plant height (unit measure) was obtained by measuring the distance from the plant collar to the soil to the apex of each plant present in the pot with the aid of a graduated ruler, with an average to compose the height of the plot; number of leaves (unit measure) by manual counting and their values expressed in units and chlorophyll index (SPAD), obtained from average of six readings performed on random sheets in the middle third of the plants, using the portable chlorophyll meter model Minolta SPAD-502.

At the time of the 55 DAE cut-off, the number of chapters (unit measure) obtained by means of counting and the diameter of chapters (unit measure) with a measurement made in the middle and cross section of the chapter was evaluated with the aid of a digital caliper.

The plants were cut close to the ground and separated into leaves + branches and chapters and packed in paper bags, identified and transferred to a drying oven with forced air circulation at $65{ }^{\circ} \mathrm{C}$ for 72 hours. After drying, material was weighed to obtain dry mass of the shoot and of chapters (unit measure).

The roots of the safflower were collected and washed on a $4 \mathrm{~mm}$ opening sieve, and to obtain the root volume, in $\mathrm{cm}^{3}$, the volume was measured in a graduated cylinder and the difference found corresponded to the root volume. The roots were conditioned in paper bags and oven dried at $65^{\circ} \mathrm{C}$ for 72 hours, after which the material was weighed to obtain root dry mass (unit measure).

The results were submitted to statistical analyses using the statistical program SISVAR (Ferreira, 2011) with analysis of variance and regression test with significance level at 1,5 and $10 \%$ probability.

\section{Results and Discussion}

Plant height at 15, 30 and 55 days after emergence (DAE), responded to the linear regression model as a function of phosphorus doses. The maximum height of $11.13,24.28$ and $27.16 \mathrm{~cm}$ plants was observed in the highest dose of the natural reactive phosphate used, with an increase of $37.30,45.72$ and $31.75 \%$, respectively, when compares the highest dose $\left(600 \mathrm{mg} \mathrm{dm}^{-3}\right)$ with the control (Figure 1).

For the third evaluation performed at 45 DAE, plant height varied significantly with soil phosphorus doses, adjusted to the quadratic regression model, with maximum height $(26.84 \mathrm{~cm})$ at the dose of $556.95 \mathrm{mg} \mathrm{dm}^{-3}$ $\left(\mathrm{P}_{2} \mathrm{O}_{5}\right)$ (Figure 1).

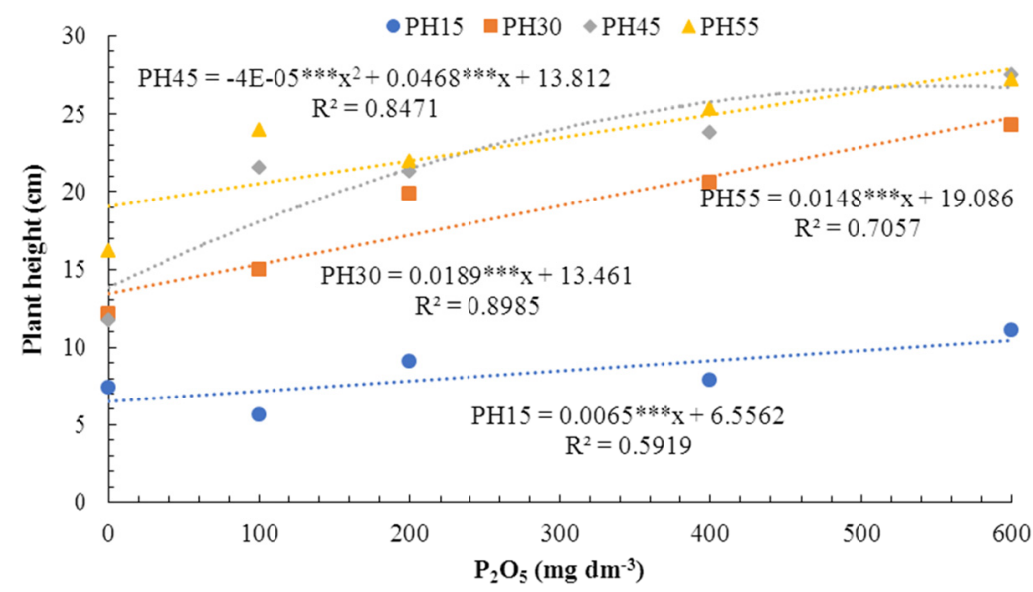

Figure 1. Plant height as a function of phosphorus $\left(\mathrm{P}_{2} \mathrm{O}_{5}\right)$ doses, with a natural phosphate source reactive at 15 , 30,45 and 55 days after emergence (DAE). *** Significant at $1 \%$ 
Phosphorus acts directly in the process of cell division in addition to energy generation of the plants, consequently, it is induced that, plants that have developed in insufficient levels of phosphorus in the soil, have lower heights that have developed in higher levels of that element (Machado, 2011), such us observed in this research.

According to Malavolta (2006), the sources of natural phosphate possess significant amounts of calcium in its composition, neutralizing the aluminum present in the soil and helping in the reduction of the concentration of hydrogen ions, making the soil propitious to the development of the roots favoring the growth of the plants.

Similar behavior to plant height was observed when the number of leaves of the safflower plants was analyzed, adjusting to a linear regression model always except the 45 DAE. When comparing the highest dose of phosphorus with the absence of fertilization, the number of leaves presented increases of 26.53,35.40 and $30.95 \%$ for the evaluations performed at 15, 30 and 55 after the emergence of the plants respectively (Figure 2). At $45 \mathrm{DAE}$, the number of leaves was significantly increased with the phosphorus doses, adjusting to the quadratic regression model, with the maximum value (16.46 leaves) provided by the dose of $500 \mathrm{mg} \mathrm{dm}^{-3}$ of $\mathrm{P}_{2} \mathrm{O}_{5}$, presenting an increase of $45.56 \%$ of production in relation to the absence of phosphate fertilization (Figure 2).

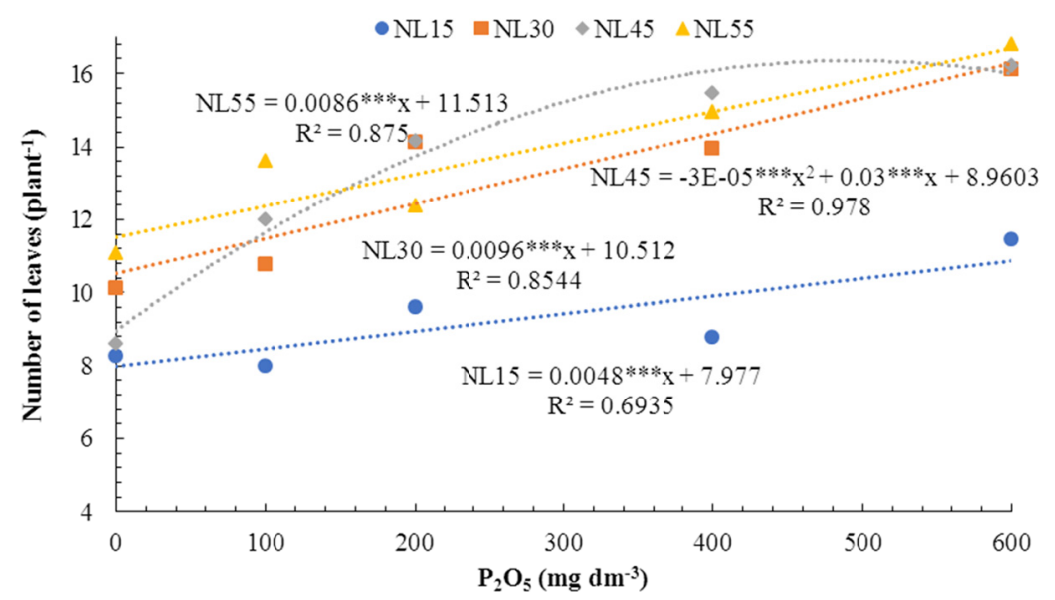

Figure 2. A number of leaves as a function of phosphorus doses $\left(\mathrm{P}_{2} \mathrm{O}_{5}\right)$ with a natural phosphate source reactive at $15,30,45$ and 55 DAE. *** Significant at $1 \%$

The linear increase in the number of leaves due to the addition of phosphorus is mainly due to the dynamics of this element, than in highly weathered soils, composed mainly of clays of the 1:1 type, which has high affinity with the soil phosphate ions end up disabling a good part of the nutrient for the solution of the soil, consequently its absorption (Raij, 1991; Novais, 1999).

Bonfim-Silva et al. (2017), analyzed the development of safflower cultivated in the same soil of the present experiment in phosphorus levels up to $540 \mathrm{mg} \mathrm{dm}^{-3}$, using triple superphosphate source and noticed a linear increase in the number of safflower leaves. This increase may have occurred mainly due to the alteration of the source used, since when fertilized with natural phosphate, the release of phosphorus to the soil solution occurs more slowly and gradually when compared to other sources of faster solubilization.

Phosphate fertilization influenced the chlorophyll content of safflower leaves, adjusting to the quadratic model of regression in the evaluation performed at $30 \mathrm{DAE}$, demonstrating that the phosphorus dose of $389.17 \mathrm{mg} \mathrm{dm}^{-3}$ was responsible for the highest chlorophyll index (50.87) with an increase of $17.86 \%$ when compared to the absence of phosphate fertilization (Figure 3).

For the evaluation performed at $45 \mathrm{DAE}$, the highest dose of natural reactive phosphate used allowed a $15.04 \%$ increase in the chlorophyll index when compared to the highest dose $\left(600 \mathrm{mg} \mathrm{dm}^{-3}\right)$ with the control (Figure 3). 


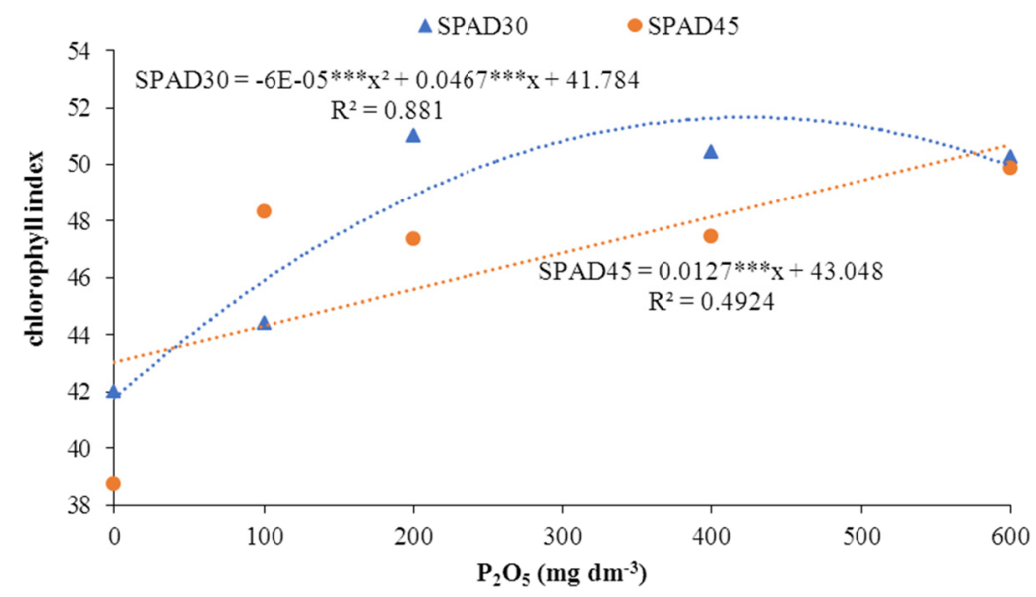

Figure 3. Chlorophyll index content (SPAD) as a function of phosphorus doses $\left(\mathrm{P}_{2} \mathrm{O}_{5}\right)$ with a natural phosphate source reactive at 30 and 45 DAE. $* * *$ Significant at $1 \%$

The chlorophyll index increased in response to phosphorus supplementation. This increase may be due to the importance of phosphorus in plant nutrition, which participates in the beneficial ATP molecule the active process of nitrogen absorption by plants (Malavolta et al., 1997; Taiz \& Zeiger, 2010), making it clear that higher phosphorus concentrations contribute to higher nitrogen uptake and higher chlorophyll content (Haim et al., 2012; Hurtado et al., 2011).

The results found in the present study corroborate with those observed by Silva et al. (2010) and Souza et al. (2011), which verified that the chlorophyll content increased with the phosphorus doses applied to the soil, suggesting that the absorption of phosphorus also favors the nitrogen absorption by the plant.

The diameter of the chapters presented a significant difference as a function of the phosphorus doses, adjusting to the quadratic model of regression in the evaluation performed at the time of the cut at 55 DAE (Figure 4A), demonstrating that the phosphorus dose of $457.17 \mathrm{mg} \mathrm{dm}^{-3}$ was responsible for the largest chapter diameter $(10.35 \mathrm{~mm})$ of safflower plants.

A

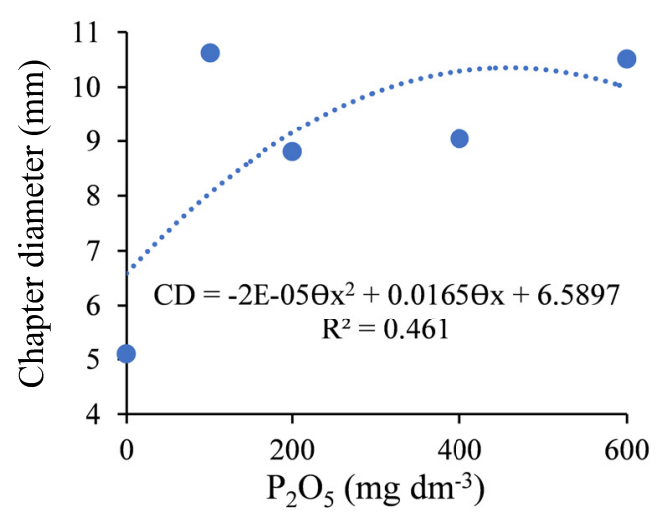

B

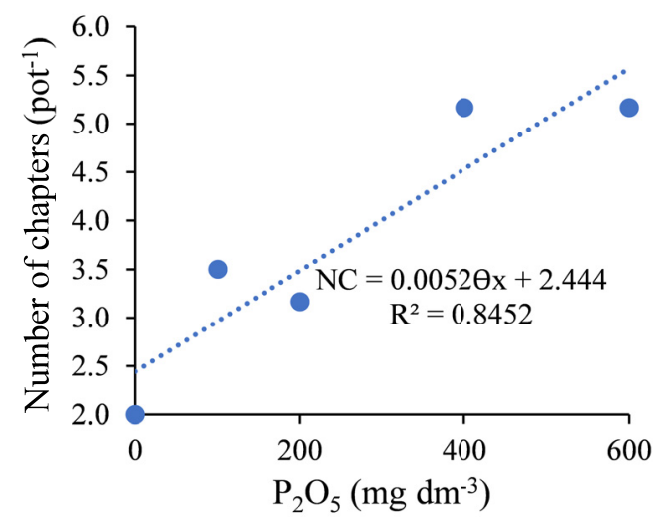

Figure 4. The diameter of chapters as a function of phosphorus doses $\left(\mathrm{P}_{2} \mathrm{O}_{5}\right)$ with natural phosphate source reactive at 55 DAE. Significant at $10 \%$

A good development of the chapter characterizes a good production of the safflower culture, the bigger the diameter of the chapter the greater the number of flowers and according to the quantity of inflorescence will be the yield of grains of the culture, with consequent increase in the oil content of the grains (Paludo et al., 2017). At the time of cutting at 55 DAE, the efficiency of the reactive natural phosphate could be perceptible, contributing to the increase in the diameter of chapters of safflower plants. Soares and Macedo (1988), that, over time, soluble phosphorus sources tend to increase their reactivity, as they have a higher residual effect. 
Abbadi and Gerendas (2011), verified that the safflower culture responds positively to the increase of phosphorus to the soil, presenting greater development and better responses in the productive variables of the safflower culture, as well as a greater number of chapters per plant, a larger diameter of chapters and a greater number of chapters in the main and secondary.

At the 55 DAE cut, there was a linear increase in the number of chapters of safflower plants with increasing doses of phosphorus (Figure 4B), whose dose of $600 \mathrm{mg} \mathrm{dm}^{-3}$ provided the highest number of chapters (5.17) with an increase of $56.15 \%$ when compared to the absence of phosphate fertilization.

The number of chapters per safflower plant is one of the most important yield components since it is directly related to the final production of the crop. According to Paludo et al. (2017), the number of chapters per plant and the number of seeds per chapter is strongly correlated with safflower productivity, as well as related to each other.

The results found in the present study corroborate those of Abbadi and Gerendas (2011), which evaluated the development of safflower and sunflower, cultivated at phosphorus doses of 8 to $150 \mathrm{mg} \mathrm{of} \mathrm{P} \mathrm{dm}^{-3}$, found that when grown with the highest dose of the element, the plants showed an increase of $83.3 \%$ on average when compared to the lower dose of calcium phosphate. Abbadi et al. (2011) found that the safflower plants are extremely demanding in phosphorus since productive variables were influenced when cultivated in low levels of both phosphorus and potassium.

The chapter dry mass of the and the shoot dry mass were significantly increased with the phosphorus doses, adjusting to the linear regression model (Figures 5A and 5B), with higher yield $\left(0.72\right.$ and $\left.0.78 \mathrm{~g} \mathrm{pot}^{-1}\right)$ in the dose of $600 \mathrm{mg} \mathrm{dm}^{-3}$ of $\mathrm{P}_{2} \mathrm{O}_{5}$ with an increase of 68.10 and $44.79 \%$ respectively, when compared to the higher dose of the experimental interval with the control.

A

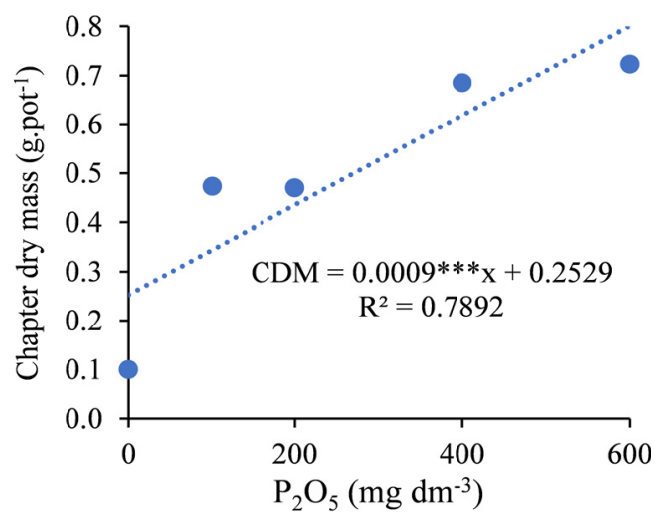

B

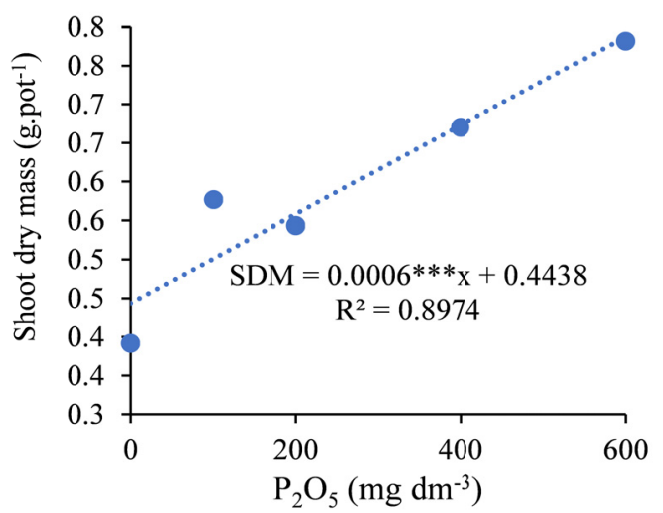

Figure 5. Chapters dry mass (A) and shoot dry mass (B) of safflower plants (Carthamus tinctorius L.) as a function of phosphorus $\left(\mathrm{P}_{2} \mathrm{O}_{5}\right)$ doses with natural phosphate source reactive at 55 DAE. *** Significance of 1\%

The positive effect of phosphatic fertilization on safflower cultivation reflects an increase in the production of dry mass of the crop, because phosphorus is directly involved in the metabolic processes of plants, playing an important role in cell energy transfer, respiration and photosynthesis as well as a constituent of several protein complexes (Malavolta et al., 1997; Zobiole et al., 2010; Tomich et al., 2003).

These results demonstrate that the root system is more developed there is a greater contact of the roots with the natural reactive phosphate incorporated in the soil, causing a greater absorption of phosphorus, favoring the growth and development of the plant, promoting greater height and as a consequence, higher production of dry mass (Chien \& Menon, 1995a, 1995b, Oliveira Junior et al., 2008).

The root volume showed a significant difference as a function of the phosphorus doses, adjusting to the linear regression model in the evaluation performed at the 55 DAE cut (Figure 6), demonstrating that the phosphorus dose of $600 \mathrm{mg} \mathrm{dm}^{-3}$ was responsible for the highest root volume $(3.57 \mathrm{ml})$ of safflower plants, increasing by $57.39 \%$ in relation to the absence of phosphate fertilization. 


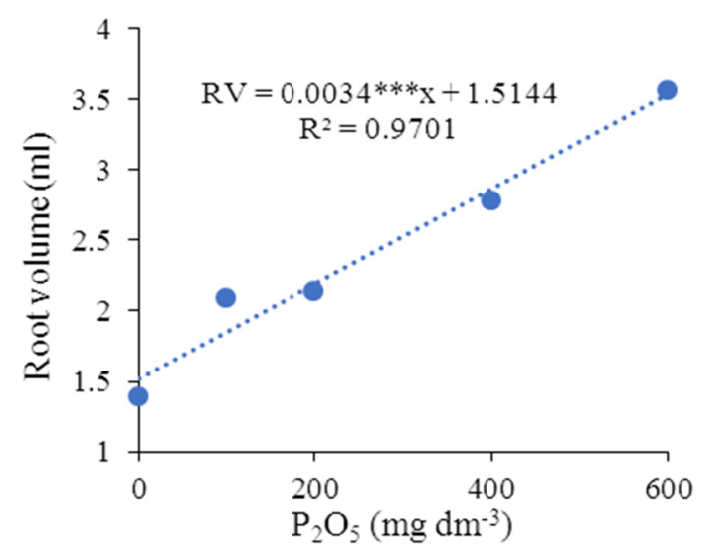

Figure 6. Root volume of safflower (Carthamus tinctorius $\mathrm{L}$.) as a function of phosphorus $\left(\mathrm{P}_{2} \mathrm{O}_{5}\right)$ doses with a natural source of phosphate reactive in the cut. $* * *$ Significance of $1 \%$

A well-developed root system is essential for plant growth, nourishment and sustenance and, as a result, a good development and increase in grain yield. According to Guedes et al. (2009), plants well-nourished mainly in phosphorus ensure a greater root development, consequently an increase in the production of photoassimilates that are redistributed to the plant, causing root growth in length and volume.

\section{Conclusions}

The natural phosphate fertilization promotes significant changes in the morphological and productive characteristics of the safflower crop.

Fertilization with Bayóvar reactive phosphate $\left(\mathrm{P}_{2} \mathrm{O}_{5}\right)$ between 389.17 and $600 \mathrm{mg} \mathrm{dm}^{-3}$ yields the best responses for the development and production of safflower cultivar IMA 0213 in Cerrado Oxisol.

The safflower presents positive responses to the application of the reactive natural phosphate as a source of phosphorus and can be an alternative for phosphate fertilization in Cerrado Oxisol.

\section{References}

Abbadi, J., \& Gerendas, J. (2011). Effects of phosphorus supply on growth, yield, and yield components of safflower and sunflower. Journal of Plant Nutrition, 34(1), 1769-1787. https://doi.org/10.1080/01904167. 2011.600405

Anicésio, E. C. A., Bonfim-Silva, E. M., Silva, T. J. A., \& Koetz, M. (2015). Dry mass, nutrient concentration and accumulation in safflower (Carthamus tinctorius L.) influenced by nitrogen and potassium fertilizations. Australian Journal of Crop Science, 9(6), 552-560.

Bonfim-Silva, E. M., Paludo, J. T. S., Sousa, J. V. R., Sousa, H. H. F., \& Silva, T. J. A. (2015). Development of safflower subjected to nitrogen rates in Cerrado soil. American Journal of Plant Sciences, 6(13), 2136-2143. https://doi.org/10.4236/ajps.2015.613215

Bonfim-Silva, E. M., Miranda, L. F. S., das Neves, L. C. R., Freitas Sousa, H. H., \& Jose, J. V. (2017). Phytometric and productive characteristics of safflower submitted to phosphate fertilization in the Oxisol of the Brazilian Cerrado. American Journal of Plant Sciences, 8(1), 2966-2976. https://doi.org/10.4236/ ajps.2017.812201

Bonfim-Silva, E. M., Silva, T. J. A., Cabral, E. A., Kroth, B. E., \& Rezende, D. (2011). Desenvolvimento inicial de gramíneas submetidas ao estresse hídrico. Revista Caatinga, 24(1), 180-186.

Bonser, A. M., Lych, J. P., \& Sieglinde, S. (1996). Effect of phosphorus deficiency on growth angle of basal roots in Phaseolus vulgaris. New Phytologist, 132(1), 281-288. https://doi.org/10.1111/j.1469-8137.1996. tb01847.x

Chien, S. H., \& Menon, R. G. (1995). Agronomic evaluation of modified phosphate rock products. IFDC's experience. Fertilizer Research, 41(1), 197-209. https://doi.org/10.1007/BF00748309

Chien, S. H., \& Menon, R. G. (1995b). Factors affecting the agronomic effectiveness of phosphate rock for direct application. Fertilizer Research, 41(1), 227-234. https://doi.org/10.1007/BF00748312 
Coronado, L. M. (2010). El cultivo Del cártamo (Carthamus tinctorius L.) en México (p. 96). Ms. D. Instituto nacional de investigacion esforestales, agrícolas y pecuárias. Ciudad Obregon-México: SGI.

Dordas, C. A., \& Sioulas, C. (2008). Safflower yield, chlorophyll content, photosynthesis, and water use efficiency response to nitrogen fertilization under rainfed conditions. Industrial Crops and Products, 27(1), 75-85. https://doi.org/10.1016/j.indcrop.2007.07.020

EMBRAPA (Empresa Brasileira de Pesquisa Agropecuária). (2006). Sistema brasileiro de classificação de solo (p. 412). Rio de Janeiro: CNPS/EMBRAPA.

EMBRAPA (Empresa Brasileira de Pesquisa Agropecuária). (2013). Sistema brasileiro de classificação de solos (3rd ed., p. 353). Brasília, DF: Embrapa.

EMBRAPA (Empresa Brasileira de Pesquisa Agropecuária). (2011). Manual de métodos de análises de solo (2nd ed., p. 230). Rio de Janeiro, RJ: Embrapa Solos.

Ferreira, D. F. (2011). Sisvar: Um sistema computacional de estatística. Ciência e Agrotecnologia, 35(1), 1039-1042. https://doi.org/10.1590/S1413-70542011000600001

Freire, F. M., Fonseca, D. M., \& Cantarutti, R. B. (2005). Manejo da fertilidade do solo em pastagens. Informe Agropecuário, 26(226), 44-53.

Guedes, E. M. S., Fernandes, A. R., Lima, E. V., Gama, M A. P., \& Silva, A. L. P. (2009). Fosfato natural de Arad e calagem e o crescimento de Brachiaria brizanta em Latossolo Amarelo sob pastagem degradada na Amazônia. Revista Ciências Agrárias, 1(52), 117-129.

Haim, P. G., Zoffoli, B. C., Zonta, E., \& Araújo, A. P. (2012). Diagnose nutricional de nitrogênio em folhas de feijoeiro pela análise digital de imagens. Pesquisa Agropecuária Brasileira, 47(10), 1546-1549. https://doi.org/10.1590/S0100-204X2012001000019

Horowitz, N., \& Meurer, E. J. (2004). Eficiência agronômica dos fosfatos naturais. In T. Yamada, S. R. S. Abdalla (Eds.), Fósforo na agricultura brasileira (pp. 665-688). Piracicaba: Potafos.

Hurtado, S. M. C., Resende, A. V., Silva, C. A., Corazza, E. J., \& Shiratsuchi, L. S. (2011). Clorofilômetro no ajuste da adubação nitrogenada em cobertura para o milho de alta produtividade. Ciência Rural, 41(1), 1011-1017. https://doi.org/10.1590/S0103-84782011005000074

Kizil, S., Çakmak, Ö., Kirici, S., \& Inan, M. (2008). A Comprehensive study on safflower (Carthamus tinctorius L.) in semi-arid conditions. Biotechnology \& Biotechnological Equipment, 22(1), 947-953. https://doi.org/ 10.1080/13102818.2008.10817585

Lima, S. O., Fidelis, R. R., \& Costa, S. J. (2007). Avaliação de fontes e doses de fósforo no estabelecimento de Brachiaria brizantha cv. Marandu no sul do Tocantins. Pesquisa Agropecuária Tropical, 37(2), 100-105.

Machado, V. J., Souza, C. H. E., Andrade, B. B., Lana, R. M. Q., \& Korndörfer, G. H. (2011). Curvas de disponibilidade de fósforo em solos com diferentes texturas após aplicação de doses crescentes de fosfato monoamônico. Bioscience Journal, 27(1), 70-76.

Malavolta, E. (2006). Manual de nutrição mineral de plantas (p. 638). São Paulo. Ceres.

Malavolta, E., Vitti, G., \& Oliveira, S. A. (1997). Avaliação do estado nutricional das plantas: princípios e aplicações (2nd ed., p. 319). Revisada e atualizada. Piracicaba: POTAFOS.

Novais, R. F. (1999). Utilização de fosfatos naturais de baixa reatividade. In A. C. Ribeiro, P. T. G. Guimarães, \& V. V. H. Alvarez (Eds.), Recomendações para o uso de corretivos e fertilizantes em Minas Gerais: $5^{a}$ aproximação (pp. 62-64). Viçosa, Comissão de Fertilidade do Solo do Estado de Minas Gerais.

Novais, R. F., \& Smyth, T. J. (1999). Fósforo em solo e planta em condições tropicais (p. 300). Viçosa, MG, Universidade Federal de Viçosa.

Oliveira Junior, A., Prochnow, L. I., \& Klepker, D. (2008). Eficiência agronômica de fosfato natural reativo na cultura da soja. Pesquisa Agropecuária Brasileira, 43(1), 623-631. https://doi.org/10.1590/S0100-204X 2008000500010

Paludo, J. S., Bonfim-Silva, E. M., Silva, T. J. A., Zanotto, M. D., Fenner, W., \& Koetz, M. (2017). Reproductive components of safflower genotypes submitted of bulk density levels in the Brazilian Cerrado. American Journal of Plant Sciences, 8(1), 2069-2082. https://doi.org/10.4236/ajps.2017.89139

Raij, B. van. (1991). Fertilidade do solo e adubação (p. 343). Piracicaba: Agronômica Ceres: Associação Brasileira para Pesquisa da Potassa e do Fosfato. 
Raij, B. van. (2011). Fertilidade do solo e manejo de nutrients (p. 420). Piracicaba, International Plant Nutrition Institute.

Rocha, A. T., Duda, G. P., Nascimento, C. W. A., \& Ribeiro, M. R. (2005). Fracionamento de fósforo e avaliação de extratores de P-disponível em solos da ilha de Fernando de Noronha. Revista Brasileira de Engenharia Agricola e Ambiental, 9(2), 178-184. https://doi.org/10.1590/S1415-43662005000200005

Shahrokhnia, M. H., \& Sepaskhah, A. R. (2016). Effects of irrigation strategies, planting methods and nitrogen fertilization on yield, water and nitrogen efficiencies of safflower. Agricultural Water Management, 172(1), 18-30. https://doi.org/10.1016/j.agwat.2016.04.010

Silva, E. F. L., Araujo, A. S. F., Santos, V. B., Nunes, L. A. P. L., \& Carneiro, R. F. V. (2010). Biological N2 Fixation in Cowpea Under Different Rates and Sources of Soluble Phosphorus. Bioscience Journal, 26(1), 394-402.

Soares, W. V., \& Macedo, C. M. (1988). Eficiência de fontes de fósforo para forrageiras em solos ácidos. In W. J. Goedert, \& F. A. Dias Filho (Eds.), Relatório bienal 1986/87-Convênio Embrapa/Petrofértil (p. 176). Brasília, Brazil.

Souza, J. A., Buzetti, S., Teixeira, M. C. M. F., Andreotti, M., Sá, M. E., \& Arf, O. (2011). Adubação nitrogenada na cultura do milho safrinha irrigado em plantio direto. Bragantia, 70(1), 447-54. https://doi.org/10.1590/ S0006-87052011000200028

Taiz, L., \& Zeiger, E. (2010). Plant Physiology (5th ed., p. 764). Sunderland: Sinauer Associates.

Tomich, T. R., Rodrigues, J. A. S., \& Gonçalves, L. C. (2003). Potencial forrageiro de cultivares de girassol produzidos na safrinha para ensilagem. Arquivo Brasileiro de Medicina Veterinária e Zootecnia, 55(6), 756-762. https://doi.org/10.1590/S0102-09352003000600013

Zobiole, L. H. S., Oliveira Junior, R. S., Huber, D. M., Constantin, J., Castro, C., Oliveira, F. A., \& Oliveira Junior., A. (2009). Glifosate reduces shoot concentrations of mineral nutrients in glifosate-resistant soybeans. Plant Soil, 328(1), 57-69. https://doi.org/10.1007/s11104-009-0081-3

\section{Copyrights}

Copyright for this article is retained by the author(s), with first publication rights granted to the journal.

This is an open-access article distributed under the terms and conditions of the Creative Commons Attribution license (http://creativecommons.org/licenses/by/4.0/). 